\title{
Annular lichenoid dermatitis of youth: A report of two cases and a review of the literature
}

\section{Gençlerin anüler likenoid dermatiti: Iki olgu sunumu ve literatürün gözden geçirilmesi}

\section{Mavișe Yüksel, ๑ Ali Balevi, ๑ Alkım Ünal Çakıter, ๑ Mustafa Özdemir, ๑ Illknur Türkmen*, ๑ Cüyan Demirkesen*}

İstanbul Medipol University Hospital, Department of Dermatology; *Department of Pathology, İstanbul, Turkey

\begin{abstract}
Annular lichenoid dermatitis of youth is a rare chronic dermatosis with an unknown cause, affecting both genders at an equal frequency. It is clinically characterized by a hypopigmented center and an erythematous border or hyperpigmented annular patches or plaques. The differential diagnosis includes annular dermatoses, such as tinea, erythema annulare centrifugum, erythema chronicum migrans, morphea, and mycosis fungoides. In this case report, we examined the clinical and histopathological features of two male patients aged 9 and 12 years with annular lichenoid dermatitis and presented their 3-year follow-up data while also reviewing the cases reported in the literature.

Keywords: Annular lichenoid dermatitis of youth, lichenoid reaction, interface dermatitis, mycosis fungoides
\end{abstract}

Öz

Gençlerin anüler likenoid dermatiti, sebebi net bilinmeyen, nadir görülen, her iki cinsiyeti de eşit sıklıkta etkileyen, kronik seyirli bir dermatozdur. Klinik olarak ortası hipopigmente, etrafı eritematöz veya hiperpigmente anüler yama veya plaklarla karakterizedir. Ayırıı tanısında tinea, eritem anüler sentrifigum, eritema kronikum migrans, morfea, mikozis fungoides (MF) gibi anüler dermatozlar yer alır. Burada anüler likenoid dermatitli 9 ve 12 yaşlarında iki erkek hastanın klinik ve histopatolojik özeliklerini irdeleyip ayıııc tanıya giren hastalıkları vurgulayıp üç yıllık takiplerini sunarken literatürde bildirilmiş olguları da gözden geçirdik.

Anahtar Kelimeler: Gençlerin anüler likenoid dermatiti, likenoid reaksiyon, interface dermatitis, mikozis fungoides

\section{Introduction}

Annular lichenoid dermatitis of youth (ALDY) is clinically characterized by asymptomatic patches or plaques on the trunk, especially on the groin, flank, and abdomen and presents with a pale center and erythematous border or hyperpigmentation. ALDY was first described by Annessi et al. ${ }^{1}$ in $2003^{2,3}$. Although clinical differential diagnosis includes inflammatory stage morphea, hypopigmented mycosis fungoides (MF), vitiligo, and erythema annulare centrifugum, pathologically, the major differential diagnosis is performed with the exclusion of lichenoid dermatitis and $\mathrm{MF}^{2,4}$. In cases of clinical suspicion, the diagnosis is made by a histopathological examination. Histopathologically, ALDY manifests as keratinocyte apoptosis on the tips of rete ridges,

Address for Correspondence/Yazışma Adresi: Mavişe Yüksel MD, İstanbul Medipol University Hospital, Department of Dermatology, İstanbul, Turkey Phone: +90 5053901779 E-mail: mavisey107@gmail.com Received/Geliș Tarihi: 07.05.2020 Accepted/Kabul Tarihi: 05.10.2020

ORCID: orcid.org/0000-0002-0011-7570

Cite this article as: Yüksel M, Balevi A, Çakıter AÜ, Özdemir M, Türkmen I, Demirkesen C. Annular lichenoid dermatitis of youth: A report of two cases and a review of the literature. Turkderm-Turk Arch Dermatol Venereol 2021;55:135-9.

(C) Copyright 2021 by Turkish Society of Dermatology and Venereology

Turkderm - Turkish Archives of Dermatology and Venereology published by Galenos Yayınevi. 
basal cell vacuolization, and band-like infiltration of T-lymphocytes predominant in the papillary dermis".

There is no known therapy for ALDY. Topical and systemic corticosteroids, topical tacrolimus, psoralen and ultraviolet $A$ radiation (PUVA), or narrow-band ultraviolet B can be used as treatment. However, recurrence usually occurs after terminating the treatment ${ }^{4}$. In this paper, we present two cases of ALDY, which is rarely described in the literature and thus does not have a clear treatment approach, and emphasize the use of tacrolimus as an important treatment option, especially in patients resistant to local steroids and recurrent cases.

\section{Case Reports}

Case 1: A 9-year-old healthy male patient presented with two asymptomatic oval annular plaques with hypopigmented centers and scaled brownish borders on the left hip and flank in July 2017. He claimed that when his complaints first started 2 months earlier, this plaque was more reddish, and then, it gradually grew, and the color of the center part faded. The patient had no disease other than allergic rhinitis. His dermatological examination revealed two plaques with hypopigmented centers and sharp borders. The first was $4 \times 6 \mathrm{~cm}$ in size and located on the left hip, and the second was $3 \times 5 \mathrm{~cm}$ in size and located on the left flank (Figure 1).

Laboratory analyses revealed normal results for complete blood count, erythrocyte sedimentation rate, liver and kidney function tests, rheumatoid factor, antinuclear antibody, anti-Borrelia antibodies, C-reactive protein (CRP), and standard patch test (European Society of Contact Dermatitis). A biopsy was performed with clinical prediagnoses of morphea, contact dermatitis, MF, and drug reaction. Based on clinical and histopathological findings, the patient was diagnosed with ALDY, and topical hydrocortisone was applied for 3 months, to which he had a partial response. Thus, $0.03 \%$ topical tacrolimus was started twice a day, and his lesions regressed clinically and histopathologically at the third month. There was no recurrence or new lesion at the $29^{\text {th }}$ month of topical tacrolimus use.

Case 2: A 12-year-old otherwise healthy male patient presented with asymptomatic plaques that first started on the left hip 4 years earlier and then appeared on the right groin and suprapubic area in February 2017. The dermatological examination of the patient revealed an approximately $4 \times 6 \mathrm{~cm}$ annular plaque with a hypopigmented center and scaled red-brownish border below, which was a $0.5 \times 1$ $\mathrm{cm}$ erythematous macule, as well as an erythematous plaque on the right groin and erythematous macule in the suprapubic area (Figure 2). Laboratory examination revealed normal results for complete blood count, erythrocyte sedimentation rate, liver and kidney function tests, rheumatoid factor, antinuclear antibodies, CRP, anti-Borrelia antibodies, and standard patch test (European Society of Contact Dermatitis). A biopsy was performed with the clinical prediagnoses of morphea and MF. According to the clinical and histopathological findings, the patient was diagnosed with ALDY and was given topical methylprednisolone aceponate for 2 months. With this treatment, the lesions became pale. Then, pimecrolimus treatment was applied for 3 months. Two months after terminating the treatment, recurrence was seen in the same locations; thus, local steroids were applied again for 2 months, followed by $0.03 \%$ topical tacrolimus twice a day. The lesions of the

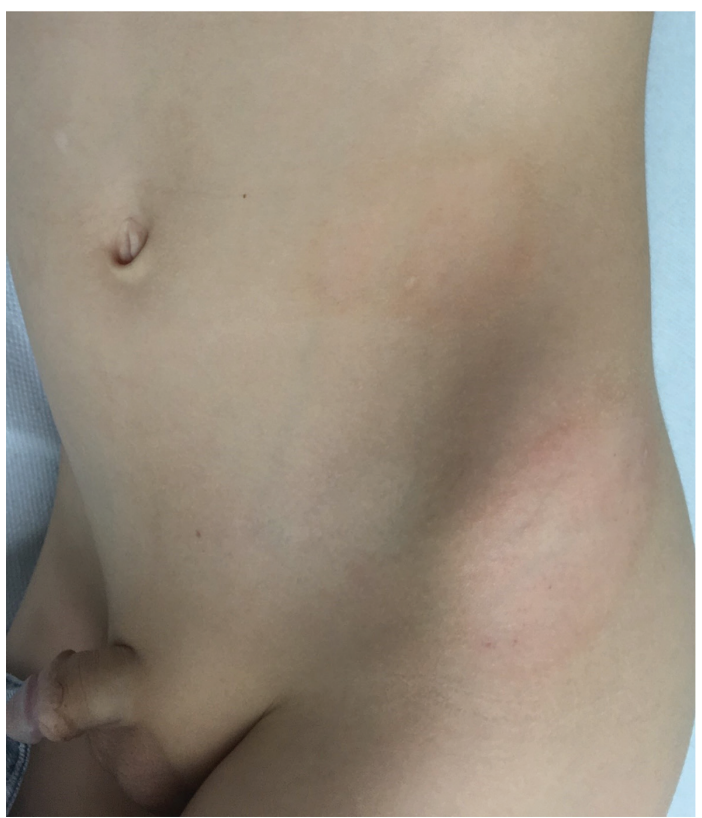

Figure 1. Two hypopigmented plaques with hypopigmented centers on the left hip and left flank of case 1

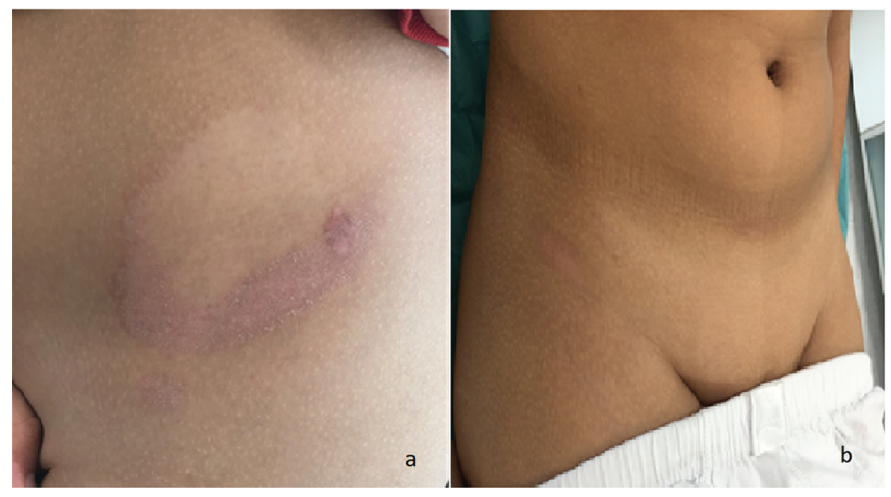

Figure 2. Images of case 2 revealing (a) a $4 \times 6 \mathrm{~cm}$ annular plaque with a hypopigmented center and red-brownish border. Below which is a $0.5 \times 1 \mathrm{~cm}$ erythematous plaque and (b) an erythematous plaque in the suprapubic area and a plaque with a hypopigmented center and erythematous border on the right groin

patient regressed at the third month of tacrolimus use. No recurrence or new lesion was detected at the $32^{\text {nd }}$ month of follow-up.

The histopathological examination was similar in two patients and was characterized by band-like infiltration of lymphocytes at the papillary dermis. Vacuolar degeneration of the basal cell layer with apoptotic cells was detected in the epidermis, intermingled with lymphocytes (Figure 3,4). The CD4/CD8 ratio was almost equal in lymphocytes (Figure 5). No loss of CD2, CD5, and CD7 was observed.

\section{Methods}

Biopsy specimens of both patients were examined by hematoxylineosin staining after routine follow-up procedures. The staining processes were performed using an automated device (Tissue Tek Prisma, Sakura, Japan). The slides were covered with a film using an automated coverslipper (Tissue Tek Film, Sakura, Japan). 
Periodic acid-Schiff (PAS) staining was routinely conducted for fungal analysis. The PAS histochemistry staining procedure was performed by Ventana BenchMark Special Stains Automated Slide stainer (Ventana, Roche, USA) histochemistry device using a PAS kit.

Staining for immunohistochemical examination was automatically performed using the Ventana Benchmark ${ }^{\circledR}$ Ultra device with the ultraVIEW Universal diaminobenzidine (DAB) detection kit, hematoxylin bluing reagent, protease 3, EZ Prep, LCS, SSC, reaction buffer, and cell conditioning CC1 solutions. This device has a two-stage system, in which deparaffinization and CC1 processes are undertaken in the first stage and antibody incubation, chromogen (diamino benzoic acid and DAB), background hematoxylin staining, and bluing processes in the second stage. Informed consent were obtained from all patient.

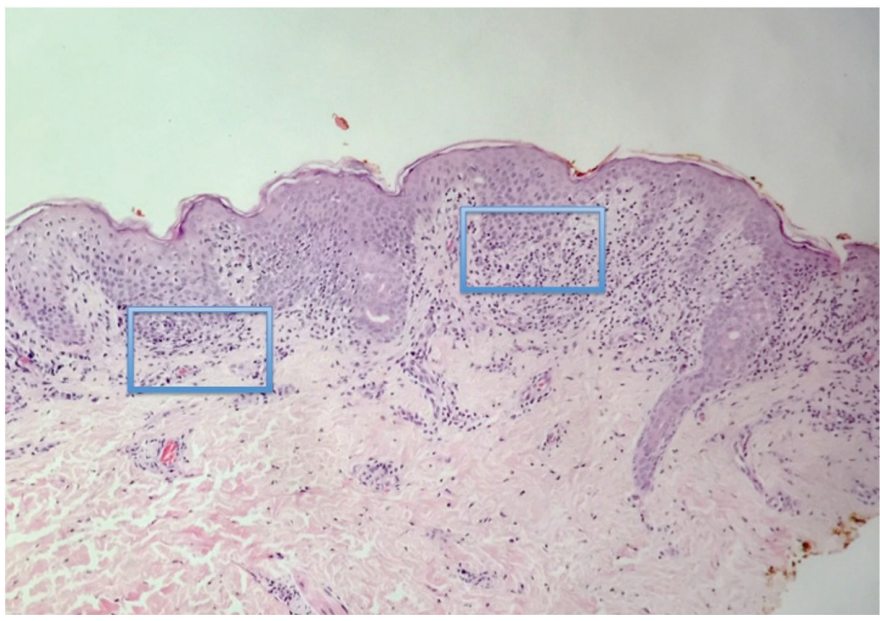

Figure 3. Pathological image showing elongation of the rete and infiltration of lymphoid cells mostly concentrated at the basal layer of the rete ridges, giving the retes a square shape (shown by blue squares) and forming a band in the papillary dermis

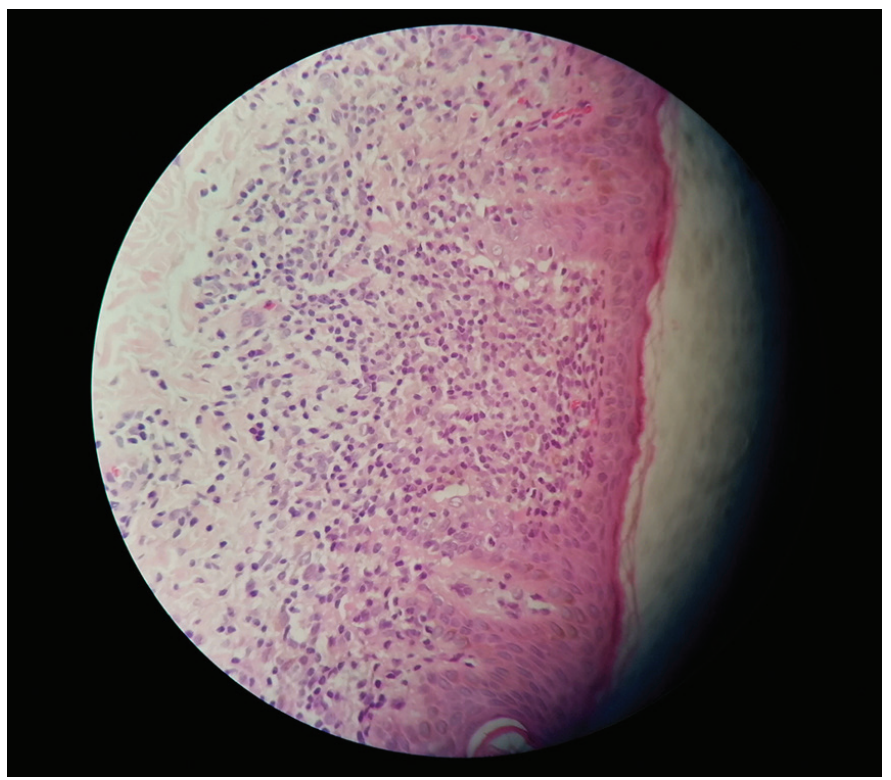

Figure 4. Pathological image at large magnification showing the bandlike infiltration of lymphoid cells and localization in the epidermis in some places. Atypia is minimal

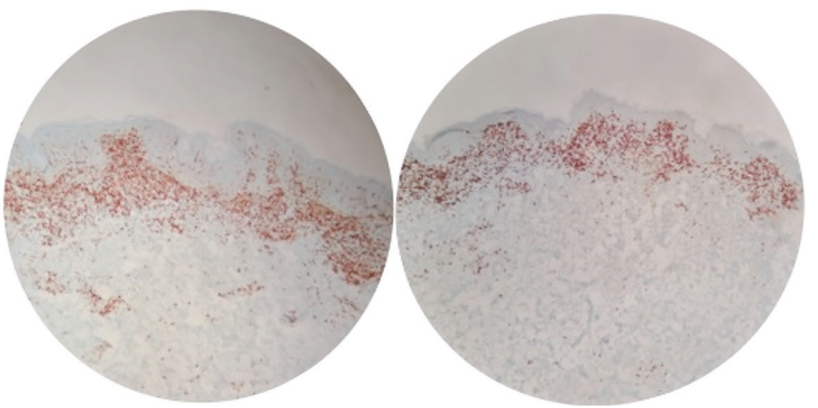

Figure 5. Immunohistochemical image showing the CD4 and CD8 rates close to 1

Table 1. Demographic and clinical characteristics of ALDY cases reported in the literature

\begin{tabular}{|c|c|c|c|c|c|}
\hline Variable & $\mathbf{n}$ & $\%$ & Variable & $\mathbf{n}$ & $\%$ \\
\hline \multicolumn{3}{|l|}{ Gender } & \multicolumn{3}{|c|}{ Lesion region } \\
\hline Male & 39 & 58.2 & Single & 28 & 41.8 \\
\hline Female & 28 & 41.8 & Multiple & 39 & 58.2 \\
\hline \multicolumn{3}{|l|}{ Country } & \multicolumn{3}{|c|}{ Lesion number } \\
\hline Mediterranean & 45 & 67.2 & Single & 17 & 25.4 \\
\hline Other Europe & 15 & 22.4 & Multiple & 50 & 74.6 \\
\hline Asia & 4 & 5.9 & $\begin{array}{l}\text { Additional } \\
\text { diseases }\end{array}$ & - & - \\
\hline America & 3 & 4.5 & None & 62 & 92.5 \\
\hline \multicolumn{3}{|l|}{ Location of lesions } & Atopy & 4 & 6 \\
\hline Flank & 33 & 49.3 & Asthma & 1 & 1.5 \\
\hline Groin & 27 & 40.3 & $\begin{array}{l}\text { Borrelia } \\
\text { serology }\end{array}$ & - & - \\
\hline Abdomen & 26 & 38.8 & Negative & 44 & 65.7 \\
\hline Axillae & 12 & 17.9 & Positive & 10 & 14.9 \\
\hline Hip & 5 & 7.5 & Not known & 13 & 19.4 \\
\hline Neck & 3 & 4.5 & Recurrence & - & - \\
\hline Back & 5 & 7.5 & Present & 34 & 50.7 \\
\hline Chest & 3 & 4.5 & Absent & 17 & 25.4 \\
\hline Upper extremities & 3 & 4.5 & Not known & 16 & 23.9 \\
\hline Breasts & 2 & 3 & $\begin{array}{l}\text { New lesion } \\
\text { emergence }\end{array}$ & - & - \\
\hline Other & - & - & Present & 6 & 9 \\
\hline Suprapubic & 1 & 1.5 & Absent & 48 & 71.6 \\
\hline Pelvic girdle & 1 & 1.5 & Not known & 13 & 19.4 \\
\hline Perianal & 1 & 1.5 & - & - & - \\
\hline Waist & 1 & 1.5 & - & - & - \\
\hline Calf & 1 & 1.5 & - & - & - \\
\hline Inframammary & 1 & 1.5 & - & - & - \\
\hline
\end{tabular}

\section{Discussion}

Since ALDY was first described in 23 patients in 2003, a total of 67 cases-39 male (58.2\%) and 28 female (41.8\%)-have been reported in the literature. Most of the reported cases are from Mediterranean 
Table 2. Treatments applied and patient responses in the case reports published in the literature

\begin{tabular}{|l|l|l|l|l|l|}
\hline Treatment & $\mathbf{n}$ & $\%$ & Patient response & $\mathbf{n}$ & $\%$ \\
\hline Topical steroids & 44 & 65.7 & $\begin{array}{l}\text { Complete } \\
\text { response }\end{array}$ & 42 & 62.7 \\
\hline Topical tacrolimus & 8 & 11.9 & Partial response & 10 & 14.9 \\
\hline Topical pimecrolimus & 2 & 3 & No response & 3 & 4.5 \\
\hline Systemic steroids & 2 & 3 & $\begin{array}{l}\text { Spontaneous } \\
\text { recovery }\end{array}$ & 6 & 9 \\
\hline Intralesional steroids & 1 & 1.5 & Not reported & 6 & 9 \\
\hline UVA1 & 2 & 3 & - & - & - \\
\hline UVB & 1 & 1.5 & - & - & - \\
\hline PUVA & 1 & 1.5 & - & - & - \\
\hline Cyclosporin & 1 & 1.5 & - & - & - \\
\hline Untreated & 9 & 13.4 & - & - & - \\
\hline Not reported & 6 & 9 & - & - & - \\
\hline UVA1: Ultraviolet A1, UVB: Ultraviolet B, PUVA: Psoralen and ultraviolet A & \\
\hline
\end{tabular}

countries, including Italy $(n=37)$, Spain $(n=3)$, Turkey $(n=3)$, France $(n=1)$, and Greece $(n=1)$. In addition, there have been published case reports in Australia ( $n=12)$, Iran and America ( $n=3$ each), and Germany, Japan, Belgium, and Serbia ( $\mathrm{n}=1$ each) ${ }^{1-21}$. Table 1 summarizes the demographic and clinical characteristics of the cases reported to date. Although annular lichenoid dermatitis is mostly seen in children and adolescents, the age distribution is wider in some series. In the case reports available in the literature, the mean age of the patients is 21.8 years, and the median age is 12 years ${ }^{1-21}$. In 2009, Cesinaro et al. ${ }^{3}$ were the first to report four patients diagnosed with annular lichenoid dermatitis who were aged 33 to 45 years and emphasized that the name of the disease should be revised to "annular lichenoid dermatitis". Di Mercurio et al. ${ }^{4}$ in 2015 also presented a case series of two patients with annular lichenoid dermatitis aged 45 and 79 years and stressed that this disease was not only seen in young people. Both our cases involved children.

After evaluating all the cases reported in the literature, the mean time from the emergence of lesions to presentation to the doctor is 7.38 months. However, our patients first visited the doctor with this complaint 2 months and 4 years after the emergence of their lesions, respectively.

\section{Discussion}

The etiopathogenesis of annular lichenoid dermatitis is not precisely known. Based on the symmetrical location of the lesions, especially in the arch area, de la Torre et al. ${ }^{5}$ suggested that an external factor might play a role in the etiology of this condition, and allergic contact dermatitis might be involved. Thus, the authors performed the European standard patch test and a patch test using the special textile dyes series with annular lichenoid dermatitis; however, the results were negative ${ }^{5}$. Wilk et al. ${ }^{6}$ serologically detected Borrelia in 9 of 12 patients diagnosed with annular lichenoid dermatitis clinically and histopathologically and included it among the possible ethological factors in the literature. In addition, Sans et al. ${ }^{7}$ reported a case that developed ALDY after hepatitis B vaccine. Our two pediatric patients had negative Borrelia serology and no hepatitis B vaccine history. Their European standard patch test results were negative.

ALDY is often characterized by single or multiple patches or plaques that start asymptomatically with a round or oval shape in the trunk, especially on the flank, groin, and abdomen, and then takes an annular shape with a diameter of about 3-10 cm. These lesions, which are initially erythematous in color, later develop a hypopigmented center and hyperpigmented border ${ }^{2}$. Of the 67 cases reported in the literature, 49.3\% had flank involvement, $40.3 \%$ had groin involvement, and $38.8 \%$ had abdominal involvement. In more than $50 \%$ of the patients, the lesions were in more than one area and multiple in number ${ }^{1-21}$. In both of our patients, the lesions were located on the flank, groin, and hip regions. In the literature, mild and moderate itching was detected in a limited number of cases $1,8,9$, but our patients did not report any itching, burning, or stinging.

Histopathological findings of ALDY vary according to the age of the lesion. In early macules, vacuolar changes and band-like infiltration of lymphocytes are observed, especially at the tips of rete ridges, whereas in late lesions, rete ridges are observed to be lost due to massive necrotic keratinocytes ${ }^{1,2}$. Our cases had similar histopathological findings to the literature, with lichenoid lymphoid infiltration and widening of some of the retes being present. Immunoprofile (equal CD4/CD8 ratio and no T-cell marker loss) helps to differentiate ALDY from MF, which is considered among the differential diagnosis both clinically and morphologically.

ALDY is confused with hypopigmented MF, especially in childhood. In histopathological differentiation, the differences between the two conditions are the absence of epidermotropism in ALDY and the absence of fibrosis in the papillary dermis, with the latter being seen in $97 \%$ of early-stage MF patients. Another disease that is investigated in the differential diagnosis of ALDY is morphea, which presents with lichenoid infiltration in contrast to ALDY. In addition, although the epidermis is flattened with lichenoid infiltrate in inflammatory vitiligo, it is hyperplastic in ALDY ${ }^{11}$.

Spontaneously regressed cases have been reported in the literature ${ }^{3,10,11}$. The treatment approach includes topical corticosteroids, pimecrolimus and tacrolimus, phototherapy ultraviolet A1 and PUVA, intralesional and systemic corticosteroids, and topical (mupirocin) and systemic antibiotics (doxycycline and cephalosporin) ${ }^{11,12}$. Although there are cases of complete remission with topical steroids and tacrolimus ${ }^{2,9,15}$, recurrence is common after treatment is terminated ${ }^{1,4}$. A review of all the case series in the literature showed that 44 patients received topical steroid treatment. Of these patients, $46.8 \%$ used topical steroids for 2 to 4 weeks and $43.2 \%$ for 4 to 8 weeks. Although $77.3 \%$ of the patients using topical steroids completely responded to treatment and their lesions regressed, $20.5 \%$ gave a partial response and $2.3 \%$ no response to topical steroids.

In the literature, of eight patients who used topical tacrolimus, 75\% completely responded to treatment, $12.5 \%$ had a partial response, and $12.5 \%$ had no response ${ }^{1-21}$. In a 9-year-old child diagnosed with ALDY, who presented with recurrence after topical steroid and UVB treatment, Stojkovic-Filipovic et al. ${ }^{12}$ applied cyclosporine treatment for 3 months and achieved complete remission in their 2-year follow-up. Table 2 presents the treatment methods used in the case series reported in the literature and the patients' responses to these treatments. Our first case had a partial response to hydrocortisone, and our second 
case had a complete response to methylprednisolone aceponate, but recurrence occurred 2 months after treatment was terminated. Topical tacrolimus was increased to $0.03 \%$, and regression was observed in both patients, and no new lesion or recurrence was detected during their follow-up.

It is essential to histopathologically differentiate ALDY from morphea, MF, and other annular dermatoses. Topical tacrolimus is an important treatment option in topical steroid-resistant or recurrent cases.

\section{Ethics}

Informed Consent: Informed consent were obtained from all patient. Peer-review: Externally peer-reviewed.

\section{Authorship Contributions}

Concept: M.Y., A.B., A.Ü.Ç., M.Ö., I.T., C.D., Design: M.Y., A.B., A.Ü.Ç., M.Ö., I.T., C.D., Data Collection or Processing: M.Y., A.B., A.Ü.Ç., M.Ö., I.T., C.D., Analysis or Interpretation: M.Y., A.B., A.Ü.Ç., M.Ö., I.T., C.D., Literature Search: M.Y., A.B., A.Ü.Ç., M.Ö., I.T., C.D., Writing: M.Y., A.B., A.Ü.Ç., M.Ö., I.T., C.D.

Conflict of Interest: No conflict of interest was declared by the authors.

Financial Disclosure: The authors declared that this study received no financial support.

\section{References}

1. Annessi G, Paradisi M, Angelo C, Perez M, Puddu P, Girolomoni G: Annular lichenoid dermatitis of youth. J Am Acad Dermatol 2003;49:1029-36.

2. Kazlouskaya $V$, Trager JD, Junkins-Hopkins JM: Annular lichenoid dermatitis of youth: a separate entity or on the spectrum of mycosis fungoides? Case report and review of the literature. J Cutan Pathol 2015;42:420-6.

3. Cesinaro AM, Sighinolfi P, Greco A, Garagnani L, Conti A, Fantini F: Annular lichenoid dermatitis of youth ... and beyond: a series of 6 cases. Am J Dermatopathol 2009;31:263-7.

4. Di Mercurio M, Gisondi P, Colato C, Schena D, Girolomoni G: Dermatology. Annular lichenoid dermatitis of youth: Report of six new cases with review of the literature. Dermatol 2015;231:195-200.

5. de la Torre C, Flórez A, Fernandez-Redondo V: Negative results of patch testing with standard and textile series in a case of annular lichenoid dermatitis of youth. J Am Acad Dermatol 2005;53:172-3.
6. Wilk M, Zelger BG, Emberger M, Zelger B: Annular lichenoid dermatitis (of youth) immunohistochemical and serological evidence for another clinical presentation of borrelia Infection in patients of Western Austria Am J Dermatopathol 2017;39:177-80.

7. Sans $V$, Leaute-Labreze $C$, Vergier $B$, Taieb $A$ : A further case of annular lichenoid dermatitis of youth: Role of the anti-hepatitis B immunization? Pediatr Dermatol 2008;25:577-9.

8. Huh W, Kanitakis J: Annular lichenoid dermatosis of youth: report of the first Japanese case and published work review. J Dermatol 2010;37:531-3.

9. Kleikamp S, Kutzner H, Frosch PJ: A Annular lichenoid dermatitis of youth-a further case in a 12-year-old girl. J Dtsch Dermatol Ges. 2008;6:653-6.

10. Tsoitis G, Kanitakis J, Kyamidis K, Asvesti K, Lefaki I: Annular lichenoid dermatitis of youth. J Eur Acad Dermatol Venereol 2009;23:1339-40.

11. Vázquez-Osorio I, González-Sabín M, Gonzalvo-Rodríguez P, Rodríguez-Díaz E: Annular lichenoid dermatitis of youth: A report of 2 cases and a review of the literature. Actas Dermosifiliogr 2016;107:e39-45.

12. Stojkovic-Filipovic J, Lekic B, Brasanac D, Lalosevic J, Gajic-Veljic M, Nikolic M: Annular lichenoid dermatitis of youth-Recurrent case of rare skin disease treated with cyclosporine. Dermatol Ther 2020;27:e13285.

13. Debois D, Dargent JL, Ngendahayo P, Roquet-Gravy PP: Annular lichenoid dermatitis of youth: A case report and literature review. Ann Dermatol Venereol 2018;145:365-75.

14. Mahmoudi H, Ghanadan A, Fahim S, Moghanlou S, Etesami I, Daneshpazhooh MJ: Anuläre lichenoide Dermatitis der Jugend: Fallberichte von zwei Erwachsenen und einem Kind. Dtsch Dermatol Ges 2019;17:11736.

15. Fabroni C, Salvini C, Piana S, Lo Scocco G: Annular lichenoid dermatitis. Clin Exp Dermatol 2010;35:921-3.

16. Leger MC, Gonzalez ME, Meehan S, Schaffer JV: Annular lichenoid dermatitis of youth in an American boy. J Am Acad Dermatol 2013;68:e155-6.

17. Ülkümen PK, Kocatürk E, Güngör \$̧, Erzurumluoğlu N: Annular lichenoid dermatitis of youth in a 15-year-old boy: Topical tacrolimus as a treatment option. Indian J Dermatol Venereol Leprol 2016;82:467.

18. Malachowski SJ, Creasey M, Kinkley N, Heaphy MR Jr: Annular lichenoid dermatitis of youth: A chronic case managed using pimecrolimus. Pediatr Dermatol. 2016;33:e360-e1.

19. Cesinaro AM: Annular lichenoid dermatitis (of youth): Report of a case with lichen planus-like features. Am J Dermatopathol 2017;39:914-5.

20. Durdu M, Baba M, Adıgüzel A, Bal N: A young case with annular lichenoid dermatitis. Turkderm-Turk Arch Dermatol Venereol 2009;43:32-4.

21. Durdu M, Akyilmaz M, Tuncer I: Annular lichenoid dermatitis of youth. Pediatr Dermatol 2007:24:582-4. 